UDC 811.111'374

https://doi.org/10.18485/bells.2018.10.4

\author{
Tvrtko Prćić \\ University of Novi Sad \\ Faculty of Philosophy \\ Novi Sad, Serbia
}

\title{
THE MAKINGS OF AN IDEAL GENERAL-PURPOSE DICTIONARY: THEORETICAL UNDERPINNINGS ${ }^{1}$
}

\begin{abstract}
This paper presents and discusses the theoretical assumptions underlying a projected ideal general-purpose dictionary. After Section 1 and some scenesetting remarks, which include a working definition of the ideal dictionary, in Section 2 the principles of modern lexicography will be concisely explained. In Section 3 the theoretical framework of the ideal dictionary will be developed in three parts dealing with its general characterization, its typological identification and a prototype specification of the ideal dictionary. By way of conclusion, in Section 4 a recapitulation of the theoretical foundation of the ideal dictionary will be accompanied by a short overview of the perspectives of its practical implementation.
\end{abstract}

Key words: ideal general-purpose dictionary, modern lexicography, general characterization, typological identification, prototype specification

E-mail address: tvrtko.prcic@gmail.com

1 To Sir, on his 85th birthday, and many more to come, in my profound gratitude for his being so motivating and obliging an MA and $\mathrm{PhD}$ adviser, a dedicated teacher and mentor, and a true friend for over three decades.

This paper is part of the research on Project No. 178002, entitled Languages and Cultures in Time and Space, which is financially supported by the Ministry of Education, Science and Technological Development of the Republic of Serbia. For valuable comments and suggestions the author's sincere thanks go to Professor Vera Vasić, Dr Jasmina Dražić and Dr Gordana Lalić Krstin. 


\section{Opening remarks}

This paper is an attempt at a description of an, or is it the?, ideal generalpurpose dictionary, concentrating on its theoretical aspects. The ideal dictionary has, of course, not yet been produced anywhere, although existing features of some current print and electronic dictionaries do qualify as conducive to the makings of an ideal dictionary. However, there are still a number of design features, sorely lacking but highly desirable, that are patiently waiting, as it were, to be recognized as necessary and/or helpful, and implemented in the ideal dictionary - of today and for the future.

Before proceeding, it may be as well to put forward a working definition of an ideal dictionary, where the modifier 'ideal' should not be interpreted as meaning, explicitly or implicitly, '(a dictionary) that is imaginary, illusory, idealistic or even quixotic, and therefore unrealistic, impracticable, utopian and, in fact, merely wishful thinking'. Rather than being chimerical, the ideal dictionary builds on down-to-earth realities, on the latest tendencies in practical and theoretical lexicography, ${ }^{2}$ which are enhanced with the author's personal observations and conceptions of what design features a really usable and useful modern dictionary should have in order to provide its potential and actual users with a wide array of options for exploiting, i.e. displaying, finding, selecting and, ultimately, benefiting from a considerably wider array of information made available to them. ${ }^{3}$

And it is the optimally balanced interplay between these two arrays, of information on offer and of options on offer, that crucially determines how well a dictionary complies with the prototype of an ideal dictionary, where 'ideal' should be construed in the sense intended here and deriving from these two fundamental design principles of the dictionary. In briefest and broadest terms, the ideal dictionary could be defined as the one that puts at users' disposal the maximum amount of information and the maximum number of options for exploiting that information. As can be inferred,

2 For extensive, detailed and useful discussions, see Al-Kasimi 1977; Atkins 1996; Atkins and Rundell 2008; Béjoint 2000, 2010; Cowie 1999; Čermák 2010; Durkin 2015; Fontenelle 2008; Hanks 2010; Hartmann 2001; Hausmann et al. 1991; Jackson 2013; Klotz and Herbst 2016; Kövecses and Csábi 2014; Landau 2001; Roberts 1992; van Sterkenburg 2003; Svensén 2009; Yong and Peng 2007; Zgusta 1971.

3 Most of these observations were made earlier, unsystematically though, in papers of diverse topics, scopes and focus, viz. Prćić 1999, 2002 / 2011: Chapter 19, 2004, 2005, 2008a, 2008b, 2010, 2012, 2013, 2014a, 2014b, 2016, 2017a, 2017b. 
the prime, and sole, purpose of the ideal dictionary is the benefit of its potential and actual users, who are provided with a powerful explanatory and educational tool made to meet as fully as possible all kinds of users' communicative and reference needs - in the ways chosen by themselves and thus achieving individualization of user experience and user exploitation of the vast resources at their fingertips.

In the upcoming paragraphs, this basic idea will be elaborated in varying degrees of generality - starting with a bird's-eye view of modern lexicography and concluding with a prototype specification of the ideal dictionary. Bearing the above fundamentals in mind, this paper has two aims: its explicit and immediate aim is to lay the theoretical foundation for the ideal dictionary, and its implicit aim is to contribute, at least modestly, to planning, devising and creating the ideal dictionary. The exposition will be organized in three sections: the principles of modern lexicography will be surveyed in Section 2; the theoretical framework of the ideal dictionary will be elaborated in three parts in Section 3; and in the concluding Section 4, a summary of the key theoretical points will be accompanied by pointers on the practicalities of producing the ideal general-purpose dictionary as conceived and depicted here.

\section{Principles of modern lexicography}

Modern lexicography, that was taking shape during the last decades of the 20th century and is seeing its rapid, dynamic, innovative and many-sided advances in the first decades of the 21st century, appears to be guided by several (unwritten) principles, which are inferable by careful observation of the dictionaries latterly and presently produced in print and/or electronic form, mostly in Britain and the United States. The central defining property of modern lexicography is, of course, modernization of the traditional lexicographic process, which is being superseded by the computer-assisted approach to doing lexicography. Even though this modernization is just an evolution of the prevalent theoretical and methodological paradigm, it has brought about, and is increasingly bringing about, revolutionary results, undreamed-of until quite recently. Thanks to global computerization and digitalization of almost all segments of the life today, making and using dictionaries in digital form have become the two hallmarks of modern lexicography - besides modernization, it is digital implementation of the 
entire lexicographic process, as its logical and ultimate outcome. There now follows the author's understanding and formulation of the principles of modern lexicography (cf. Prćić 2016b, 2016c, on which this account draws):

(1) Modern lexicography is founded on SCIENTIFIC PRINCIPLES AND METHODS, which means the application of the latest theoretical, methodological and practical achievements of current lexicography and lexicology, as well as corpus, cognitive, contrastive and contact linguistics. The unifying research basis to all these disciplines is pragmaticization (alternatively, contextualization, or concretization, of meanings), consisting in the examination of language phenomena as they manifest themselves in reallife linguistic and extralinguistic contexts, which makes it possible to carry out analyses of authentic, naturally occurring stretches of written and spoken language at all levels of their use. As a result, linguistic researchers, including lexicographers, can obtain objective insights into actual lexical, grammatical and other usage phenomena, and can thus assure their full and reliable lexicographic treatment, freed from subjective and intuitive judgements of dictionary editors and compilers regarding acceptable and/ or recommended usage.

(2) Modern lexicography assists in producing FUNCTION-DRIVEN DICTIONARIES, which means focus, firstly, on the passive (receptive) function, related to users' understanding of written and spoken texts in L1; and/or, secondly, on the active (productive) function, related to users' expressing themselves in speech and writing in L1 or, when translating or learning a foreign or second language, in L2; and/or, thirdly, on the mediatory function, related to users' understanding of texts with the aid of translation and/or to users' translating of texts from L1 into L2. In recent decades there has been a marked tendency, initiated in British learner's dictionaries, to conflate passive and active functions within one dictionary, and even all three functions within hybrid bilingualized dictionaries, in which the text of a monolingual, typically learner's, dictionary is enhanced with translations of definitions, word senses and examples into another language, typically the learner's mother tongue. ${ }^{4}$ And the fourth, metalexical function, related to providing users with insights into form- and contentbased workings of vocabulary, is implicitly covered in all dictionaries and

4 For pioneering reports on the compilation, exploitation and assessment of bilingualized EFL dictionaries, see Baker and Kaplan 1994; Hartmann 1994; Laufer and Hadar 1997; Laufer and Kimmel 1997; Laufer and Melamed 1994. 
explicitly in specialized dictionaries, dealing with segments of vocabulary, like synonyms, collocations or affixes.

(3) Modern lexicography focuses on producing USER-ORIENTED DICTIONARIES, which means fulfilling users' expected communicative needs in terms of completeness, accuracy and usability of the information offered, in accordance with the type, purpose and function of the dictionary. In addition to customary linguistic information about the forms, functions, meanings and uses of words, and their combinations and components, it is desirable also to include, where/when necessary and feasible, encyclopedic information on the cultural and even conceptual system of L1 and, in bilingual dictionaries, of L2.

(4) Modern lexicography focuses on producing USER-FRIENDLY DICTIONARIES, which means fulfilling users' expected reference needs in terms of accessibility of dictionaries and, particularly, quick and effortless findability of the information sought. This is achieved, firstly, with a detailed user's guide, explaining the methods of processing, editing and presenting the information offered; secondly, with an easily navigable multi-paragraph layout of a dictionary entry; thirdly, with effective typography, employing, in moderation, fonts of various faces, sizes and colours; and fourthly, with abstruse abbreviations and symbols reduced to an absolute minimum, if not eliminated altogether.

The latter two principles, user-orientation and user-friendliness, are two complementary facets of one unique property of modern lexicography - user-centredness, directed towards meeting the needs of potential and actual dictionary users, who represent the primary goal and motivating force of every modern dictionary planned and/or implemented today.

(5) Modern lexicography promotes DIGITAL IMPLEMENTATION of the lexicographic process, which means computer-assisted lexicography, discharged in digital, or electronic, form during all four stages of this process: firstly, in collecting and selecting written and spoken language material to be used as an electronic reference corpus; secondly, in processing, editing and presenting information in dictionaries; thirdly, in producing, realizing, publishing and distributing dictionaries; and fourthly, in utilizing dictionaries as final products. Digital implementation is subsumable under the concept and term electronic lexicography, or e-lexicography, ${ }^{5}$ for short,

5 For groundbreaking contributions to theoretical, methodological and practical aspects of electronic lexicography, see Fuertes-Olivera and Bergenholtz 2013; Gouws et al. 2013; Granger and Paquot 2012; Kosem and Kosem 2011; Kosem et al. 2013, 2015, 2017. 
which highlights and determines the theoretical, methodological and practical identity, and intrinsic nature, of modern lexicography.

With the above five principles in full swing, the way could be seen to be paved for the recognition, in time, of a sixth, brand new, principle of modern lexicography, which says:

(6) Modern lexicography stimulates institutional DEVELOPMENT OF DICTIONARY CULTURE, which consists in popularization of lexicography, firstly, by acquainting would-be users with different types and purposes of dictionaries and, secondly, by teaching and monitoring efficient dictionary use, especially within the educational system, starting from senior classes of the primary school onwards, and culminating at the university - specifically in courses on language(s) and linguistics. In this manner, forming part of general language culture (cf. Bugarski 1997a, 1997b), the foundation would be laid for the establishment and institutional development of dictionary culture, particularly among people professionally engaged in using language publicly, often to linguistically receptive and impressionable audiences. Dictionary culture could be defined as an acquired ability to use dictionaries efficiently coupled with the habit of resolving all usage-related problems (about vocabulary, grammar, pronunciation, spelling, etc.) and filling gaps in linguistic knowledge by regularly consulting dictionaries and other reference tools rather than pursuing the self-deceptive practice of relying only on one's own shaky personal intuition.

\section{Theoretical framework of the ideal dictionary}

This section brings in-depth discussions of three important and interconnected sets of theoretical issues related to the organization of the ideal dictionary, each within its own separate subsection: its general characterization (3.1), its typological identification (3.2), and a prototype specification of the ideal dictionary (3.3).

\subsection{General characterization of the dictionary}

At the outset, it is necessary to determine the TARGET AUDIENCE OF USERS of the ideal dictionary and their communicative and reference needs, because together they dictate the overall structure and organization of any dictionary. Here, the audience is projected to consist of a very wide spectrum of users, 
of various ages, vocations and interests, typically starting from those around the age of 15 , at senior classes of the primary school onwards, catering for native speakers and foreign learners of a language, or languages, alike. Users' communicative needs are seen to comprise all four dictionary functions mentioned above - passive, active, mediatory and metalexical, and to cater equally for the practical, everyday needs of ordinary, nonspecialist users and for the theoretical, research needs of extra-ordinary, specialist users, chiefly professional linguists. Users' reference needs are tuned to ensure that the information put at their disposal is attractively presented, quickly accessible, readily understandable and easily applicable by potential and actual users.

With this projection of target users and their communicative and reference needs, it is now possible to set the aims that the compilation of the ideal dictionary should accomplish (the inventory of aims and their naming build around the model originally presented in Prćić 2012 and the formulations, in part, follow those in Prćić 2016c).

(1) The dictionary's COMMUNICATIVE, AND PRINCIPAL, AIM is to construct a complete picture of the vocabulary of one individual language, here referred to as the primary language, coupled, if so desired by the user, with at least one other language, or more languages, up to five, here referred to as the secondary language(s). The vocabularies analysed and described would be treated as intralingually and interlingually connected lexical networks and, for this reason, the information offered would be composed of three interconnected dimensions:

- information about forms, functions, meanings and uses of words and idioms, as word combinations, in the primary language and, if so desired, in comparison with at least one secondary language,

- information about forms, functions and meanings of affixes and combining forms, as word components, in the primary language and, if so desired, in comparison with at least one other language, and

- information about paradigmatic,syntagmatic and word-formational interrelations of words, word combinations and components in the primary language and, if so desired, in comparison with at least one secondary language.

When the dictionary is set to display information about one language, it works in the monolingual mode; when two languages are selected, it is in the bilingual mode; and when between three and five languages are active, it is in the multilingual mode. The inclusion of these three dimensions of 
information - equally in mono-, bi- and multilingual modes - would help users in three intended respects:

- to appropriately understand written and spoken texts in one or more languages,

- to appropriately create written and spoken texts in one or more languages, and

- to appropriately translate written and spoken texts from one language into another, and vice versa.

(2) The dictionary's DESCRIPTIVE AIM is to offer a comprehensive, detailed and reliable account of the authentic use of words, their combinations and components by codifying their typical behaviour in one or more languages, individually and/or contrastively, at the levels of graphology, phonology, morphology, syntax, semantics, stylistics and pragmatics, as well as on the planes of paradigmatics, syntagmatics and word formation.

(3) The dictionary's PRESCRIPTIVE AIM is to indicate systematic departures from the standard usage of words and their combinations in one or more languages, individually and/or contrastively, and to recommend their standard uses when there are cases of variation or misuse in terms of graphology, phonology, morphology, syntax, semantics, stylistics and pragmatics.

(4) The dictionary's METALEXICAL AIM is to afford a revealing insight into the functioning of the lexical system of one or more languages, individually and/or contrastively, especially in respect of the form- and/or contentbased interrelations of words on the paradigmatic, syntagmatic and wordformational planes.

(5) The dictionary's LEXICOGRAPHIC AIM is to present information about words, their combinations and components in an easily navigable, typographically effective and, above all, user-friendly manner, in conformity with the latest design trends of modern practical and theoretical lexicography.

(6) The dictionary's EDUCATIONAL AND, PARTLY, SOCIOLINGUISTIC, AIM is to raise users' awareness about the importance of developing a regular habit of resolving lexical and other usage-related problems and of filling gaps in linguistic knowledge by consulting dictionaries and other reference books, thereby contributing to the building and fostering of dictionary culture rather than relying only on their own subjective, and often shaky, linguistic intuitions and judgements. 


\subsection{Typological identification of the dictionary}

Typological features of the ideal dictionary have been determined in accordance with the customary criteria and standards laid out for classifications of dictionaries (cf. Atkins and Rundell 2008; Hartmann 2001; Lipka 2002; van Sterkenburg 2003; Svensén 2009; Zgusta 1971). The typological profile of this particular dictionary, as it has been conceived, can be created with the following ten defining lexicographic features (the inventory of feature types also builds around the model originally presented in Prćić 2012):

(1) A MONOLINGUAL dictionary, with an integrated BILINGUAL AND/OR MULTILINGUAL dictionary, in that it will contain information about the primary language and between two and five secondary languages contrastively.

(2) A sYNCHRONIC dictionary, in that it will cover current, turn-of-thecentury lexical resources of each language, spanning roughly a fifty-year period, from the 1970's until the present.

(3) A GENERAL-PURPOSE dictionary, in that it will cover general, everyday, non-specialist vocabulary of each language.

(4) A Dictionary, with elements of a thesaurus, in that it will include information about content-based interrelations of words, their combinations and components.

(5) A SEMASIOLOGICAL dictionary, with elements of an ONOMASIOLOGICAL dictionary, in that sense-relatedness of clusters of words starts from the shared meaning and goes towards words expressing nuances of shared meaning, unlike the other method which starts from words and goes towards the meanings they express.

(6) A dictionary combining THREE METHODS of dealing with linguistic data, in that it will employ descriptive, prescriptive and metalexical approaches, to account for actual language use, to point out systematic errors in use and recommend standard uses, and to picture the paradigmatic and syntagmatic organization of vocabulary, respectively.

(7) A dictionary combining FOUR FUnCTIONS, in that it will be designed so as to serve passive (receptive), active (productive), mediatory and metalexical dictionary functions and in this way to satisfy all communicative needs of potential and actual users.

(8) A MEDIUM-SIZED dictionary, in that it will comprise between 100,000 and 150,000 headwords per language, inclusive of words and word components, and exclusive of word combinations, being treated as subheadwords. 
(9) A DIGITAL, or ELECTRONIC, dictionary, in that it will be realized in electronic form and adapted to be utilized either online or offline.

(10) An ALPHABETICAL dictionary, with elements of a CONCEPTUAL dictionary, in that thesaural information about content-based interrelations of words will be organized around sense-relatedness of clusters of words.

It can be noticed in the above typological identification that as many as six of the ten lexicographic feature types have at least two correlative features merged within one type. Typological features like these contribute to the hybrid nature of this dictionary (cf. Hartmann 2005), which is a more than welcome and desirable characteristic of any modern dictionary, especially one which aims to become an ideal general-purpose dictionary.

\subsection{Prototype specification of the ideal general-purpose dictionary}

Having hitherto dealt with the distinguishing characteristics of modern lexicography and, from two viewpoints, of the ideal general-purpose dictionary, it now becomes possible to identify the characteristics that would uniquely determine the makings of the prototypical ideal general-purpose dictionary. Without aspiring to either exhaustiveness or definitiveness, but rather to a realistic and representative design feature specification, it will be suggested here that the ideal dictionary is prototypified by the following ten essential and salient design features (cf. Prćić 2014a, 2014b, 2016, 2017a, 2017b):

(1) Digital (electronic) form of compilation, realization, distribution and exploitation, online and/or offline, of the dictionary - this involves paperless lexicography, characterized by the use of latest computer technology in all four stages of the lexicographic process.

(2) UNIVERSAL FREE ACCESSIBILITY of all the content made available to users - this involves open and unrestricted access over the internet to the full dictionary content without obliging users to pay, subscribe or register in any way in order to become entitled to consult it.

(3) Corpus-based methodology for collection, extraction, description and codification of lexical and other information made available to users - this involves exploitation of large electronic reference corpora, of no fewer than 500 million words per language, with each corpus containing written and spoken samples of authentic use.

(4) USER-CENTREDNESS in selection, preparation, organization, presentation and, above all, exploitability of the content made available 
to users - this involves tailoring the design of the dictionary so as to meet as best as possible users' communicative and reference needs, firstly, by offering as much as possible relevant information about words, their combinations and components, and secondly, by offering as many as possible options for fully customizing the quantity and quality of the information shown to users. With a focus slightly shifted, the totality of the information at users' disposal is intended for all potential users, whereas the totality of customization options is intended for single actual users and their individual(ized) preferences for receiving new information.

(5) USER-CONTROLLABLE INTERACTIVITY in selection of dictionary modules and features - this involves individualization of user exploitation and user experience of the dictionary, which is achieved by letting users set the primary and secondary language modules, most of the information types to be displayed and ways of their typographical presentation onscreen; with the inescapable exception of the default and lexicographically indispensable headwords, their parts of speech, definitions and, when bilingual modules are on, their translations into the secondary language(s), users are in full control of the appearance of all microstructural features regarding the lexicographic treatment of phonology, morphosyntax, semantics-cum-pragmatics, stylistics, exemplifications, cross-references and, within dedicated thematic boxes, of paradigmatic, syntagmatic and word-formational interrelations, and of moot usage points.

(6) Multimedia ENRichment of textual content with illustrative audio, video and graphic content, retrievable internally or externally - this involves segments of recorded speech, sounds and music, of moving visual images and of still visual images, respectively, either incorporated into the dictionary itself or accessed from a remote computer.

(7) HYPERLINKED CROSS-REFERENCING to specific portions of textual and/ or multimedia content, internally or externally retrievable - this involves extensive interconnection of both headwords and information about them, presented in textual and/or multimedia form, largely for comparative and/ or illustrative purposes, and activated either by clicking or by touching highlighted on-screen links.

(8) EASY SEARCHABILITY of headwords according to simple or complex preset criteria, including wildcard searches for word beginnings, middles and endings - this involves user-selectable isolation from words of specific prefixes, initial combining forms, infixes, suffixes and final combining forms, their combinations and/or other letter or sound patterns. 
(9) USER COLLABORATION in contributing to dictionary editors documented candidates for new headwords and/or new meanings of existing ones - this involves crowdsourcing in obtaining potential additions, i.e. formal and semantic neologisms, and thus approaching to a moderately controlled open dictionary, where users' input is subject to editors' approval and corpus-based lexicographic treatment.

(10) Periodic Editorial updatability of the content with new headwords, information about them or emendations of existing information - this involves regular, at least biannual, revision process which consists of adding fresh content and correcting inaccuracies, so as to ensure that the information made available is always up-to-date, precise and reliable, as much as this is attainable.

\section{Closing remarks: summing up and looking ahead}

This paper has proposed and examined the theoretical underpinning behind the makings of a future ideal general-purpose dictionary, which has been conceived in keeping with the principles of modern lexicography. The ideal dictionary has been described from three angles: firstly, the set of aims to be accomplished by its compilation (under the heading of general characterization); secondly, the set of its defining lexicographic features (under the heading of typological identification); and thirdly, the set of essential and salient design features of a prototypical ideal general-purpose dictionary (under the heading of prototype specification).

Following naturally from this theoretical analysis of the makings of the ideal dictionary would be the making of the ideal dictionary. Its practical implementation would entail, firstly, a carefully built macrostructure, i.e. an ordered list of lexical items that are the object of lexicographic description (cf. Hartmann and James 1998) - comprising words, affixes and combining forms, serving as headwords, and idioms, serving as subheadwords; and, secondly, a meticulously thought out microstructure, i.e. an ordered set of information types provided on words, affixes, combining forms and idioms, and their form- and content-based interrelations (cf. Hartmann and James 1998) - in the domains of graphology, phonology, morphosyntax, semantics-cum-pragmatics, stylistics, exemplifications, cross-references, of paradigmatic, syntagmatic and word-formational planes and of usage / misusage points. However, because of their great importance 
and complexity, the practicalities of the ideal general-purpose dictionary would call for, and deserve, a separate paper-length treatment, in which sorely lacking but highly desirable design features, mentioned at the very beginning of this paper, would be given due consideration and in-depth coverage.

\section{References}

Al-Kasimi, A. (1977). Linguistics and Bilingual Dictionaries. Leiden: E. J. Brill.

Atkins, B. T. S. (1996). Bilingual Dictionaries: Past, Present and Future. In: M. Gellerstam et al. (eds.), Euralex '96 Proceedings I-II, Part II, Göteborg: Göteborg University, Department of Swedish, 515-546. <http://euralex.org/category/publications/euralex-1996-2/>.

Atkins, B. T. S. and M. Rundell (2008). The Oxford Guide to Practical Lexicography. Oxford: Oxford University Press.

Baker, M. and R. B. Kaplan (1994). Translated! A New Breed of Bilingual Dictionaries. Babel, 40/1, 1-11.

Béjoint, H. (2000). Modern Lexicography. An Introduction. Oxford: Oxford University Press.

Béjoint, H. (2010). The Lexicography of English. Oxford: Oxford University Press.

Bugarski, R. (1997a). Kultura u jeziku i jezička kultura. U: Jezik u kontekstu, Beograd: Čigoja štampa, XX vek, 244-249.

Bugarski, R. (1997b). Lingvistika i jezička kultura. U: Jezik u kontekstu, Beograd: Čigoja štampa, XX vek, 250-256.

Cowie, A. P. (1999). English Dictionaries for Foreign Learners. A History. Oxford: Clarendon Press.

Čermák, F. (2010). Notes on Compiling a Corpus-Based Dictionary. Lexikos, 20, 559-579. <http://lexikos.journals.ac.za/pub/article/ download/156/98>.

Durkin, Ph. (ed.). (2015). The Oxford Handbook of Lexicography. Oxford: Oxford University Press.

Fontenelle, T. (ed.). (2008). Practical Lexicography. A Reader. Oxford: Oxford University Press.

Fuertes-Olivera, P. A. and H. Bergenholtz (eds.). (2013). e-Lexicography. The Internet, Digital Initiatives and Lexicography. London: Bloomsbury Academic. 
Gouws, R. H. et al. (eds.). (2013). Dictionaries. An International Encyclopedia of Lexicography. Supplementary Volume: Recent Developments with Focus on Electronic and Computational Lexicography. Berlin: De Gruyter Mouton.

Granger, S. and M. Paquot (eds.). (2012). Electronic Lexicography. Oxford: Oxford University Press.

Hanks, P. (2010). Compiling a Monolingual Dictionary for Native Speakers. Lexikos, 20, 580-598. <http://lexikos.journals.ac.za/pub/article/ download/157/99>.

Hartmann, R. R. K. (1994). Bilingualised Versions of Learners' Dictionaries. Fremdsprachen Lehren und Lernen, 23, 206-220.

Hartmann, R. R. K. (2001). Teaching and Researching Lexicography. Harlow: Pearson Education.

Hartmann, R. R. K. (2005). Pure or Hybrid? The Development of Mixed Dictionary Genres. Facta Universitatis. Series: Linguistics and Literature, 3/2, 193-208. <http://facta.junis.ni.ac.rs/lal/lal2005/lal2005-06.html>.

Hartmann, R. R. K. and G. James (1998). Dictionary of Lexicography. London/New York: Routledge.

Hausmann, F. J. et al. (eds.). (1991). Wörterbücher. Ein internationales Handbuch zur Lexikographie / Dictionaries. An International Encyclopedia of Lexicography / Dictionnaires. Encyclopédie internationale de lexicographie. 1-3. Berlin/New York: Walter de Gruyter.

Jackson, H. (ed.). (2013). The Bloomsbury Companion to Lexicography. London: Bloomsbury Academic.

Klotz, M. and Th. Herbst (2016). English Dictionaries. A Linguistic Introduction. Berlin: Erich Schmidt Verlag.

Kosem, I. and K. Kosem (eds.). (2011). Electronic Lexicography in the 21st Century. New Applications for New Users. Ljubljana: Trojina, Institute for Applied Slovene Studies. (10 November 2017) <http://elex2011. trojina.si/elex2011_proceedings.pdf $>$.

Kosem, I. et al. (eds.). (2013). Electronic Lexicography in the 21st Century. Thinking Outside the Paper. Ljubljana: Trojina, Institute for Applied Slovene Studies; Tallinn: Eesti Keele Instituut. (10 November 2017) $<$ http://eki.ee/elex2013/proceedings/eLex2013-proceedings.pdf > .

Kosem, I. et al. (eds.). (2015). Electronic Lexicography in the 21st Century. Linking Lexical Data in the Digital Age. Ljubljana: Trojina, Institute for Applied Slovene Studies; Brighton: Lexical Computing Ltd. (10 November 2017) <https://elex.link/elex2015/wp-content/uploads/ eLex2015-proceedings.pdf $>$. 
Kosem, I. et al. (eds.). (2017). Electronic Lexicography in the 21st Century. Lexicography from Scratch. Brno: Lexical Computing, CZ s.r.o. (10 November 2017) <https://elex.link/elex2017/proceedings/eLex_ 2017_Proceedings.pdf $>$.

Kövecses, Z. and Sz. Csábi (2014). Lexicography and Cognitive Linguistics. Revista Española de Lingüística Aplicada / Spanish Journal of Applied Linguistics, 27/1, 118-139.

Landau, S. I. (2001). Dictionaries. The Art and Craft of Lexicography. 2nd edition. Cambridge: Cambridge University Press.

Laufer, B. and L. Hadar (1997). Assessing the Effectiveness of Monolingual, Bilingual and 'Bilingualised' Dictionaries. The Modern Language Journal, 81/2, 189-196.

Laufer, B. and M. Kimmel (1997). Bilingualised Dictionaries: How Learners Really Use Them. System, 25/3, 361-369.

Laufer, B. and L. Melamed (1994). Monolingual, Bilingual and 'Bilingualised' Dictionaries: Which Are More Effective, for What and for Whom?. In: W. Martin et al. (eds.), Euralex '94 Proceedings, Amsterdam: Vrije Universiteit, 565-576. <http://euralex.org/category/publications/ euralex-1994/>.

Prćić, T. (1999). The Treatment of Affixes in the 'Big Four' EFL Dictionaries. International Journal of Lexicography, 12/4, 263-279.

Prćić, T. (2002). Dvojezična leksikografija i englesko-srpski / srpsko-engleski opšti rečnik: potrebe i zahtevi novog veka. U: Deskriptivna leksikografija standardnog jezika i njene teorijske osnove, Beograd: Srpska akademija nauka i umetnosti; Novi Sad: Matica srpska; Beograd: Institut za srpski jezik SANU, 331-342.

Prćić, T. (2004). Enter the 'Big Fifth' EFL Dictionary: Macmillan English Dictionary for Advanced Learners. Lexicographica, 20, 303-322.

Prćić, T. (2005). Prefixes vs Initial Combining Forms in English: A Lexicographic Perspective. International Journal of Lexicography, 18/3, $313-334$.

Prćić, T. (2008a). Suffixes vs Final Combining Forms in English: A Lexicographic Perspective. International Journal of Lexicography, 21/1, 1-22.

Prćić, T. (2008b). Culture-Specific Words and How to Deal with Them in Bilingual Dictionaries. In: K. Rasulić and I. Trbojević Milošević (eds.), International Conference "English Language and Literature Studies: Structures across Cultures". ELLSSAC Proceedings, Vol. 1, Belgrade: Faculty of Philology, 415-421. 
Prćić, T. (2010). Mali englesko-srpski rečnik pragmatičkih termina. U: V. Vasić (ur.), Diskurs i diskursi. Zbornik u čast Svenki Savić, Novi Sad: Filozofski fakultet, 399-415.

Prćić, T. (2011). Engleski u srpskom. Drugo izdanje. Novi Sad: Filozofski fakultet.

Prćić, T. (2012). Chapter 6. Lexicographic Description of Recent Anglicisms in Serbian: the Project and Its Results. In: C. Furiassi et al. (eds.), The Anglicization of European Lexis, Amsterdam/Philadelphia: John Benjamins Publishing Company, 131-148.

Prćić, T. (2013). Du yu speak anglosrpski? Rečnik novijih anglicizama deset godina posle: da li je vredelo?. U: S. Gudurić (ur.), Jezici i kulture u vremenu i prostoru I. Tematski zbornik, Novi Sad: Filozofski fakultet, 253264. <http://digitalna.ff.uns.ac.rs/sadrzaj/2012/978-86-6065-133-6> .

Prćić, T. (2014a). Kakvi nam englesko-srpski i srpsko-engleski rečnici najviše trebaju. U: T. Prćić, M. Marković, i dr. (ur.), Engleski jezik i anglofone književnosti u teoriji i praksi. Zbornik u čast Draginji Pervaz, Novi Sad: Filozofski fakultet, Orfelin izdavaštvo, 419-442. < http://digitalna. ff.uns.ac.rs/sadrzaj/2014/978-86-6065-276-0>.

Prćić, T. (2014b). Novi rečnik novijih anglicizama: zašto, šta i kako. U: M. Alanović, i dr. (ur.), Leksika, gramatika, diskurs. Zbornik u čast Veri Vasić, Novi Sad: Filozofski fakultet, 41-58. < http://digitalna.ff.uns. ac.rs/sadrzaj/2013/978-86-6065-193-0>.

Prćić, T. (2016). Kakav nam opšti rečnik srpskog jezika najviše treba. U: S. Ristić, i dr. (ur.), Leksikologija i leksikografija u svetlu savremenih pristupa. Zbornik naučnih radova, Beograd: Institut za srpski jezik SANU, 87-117. <https:// zenodo.org/record/437541/files/Leksikologija\%2003Prcic.pdf>.

Prćić, T. (2017a). Kakav nam specijalizovani rečnik srpskog jezika najviše treba. U: R. Dragićević (ur.), Putevima reči. Zbornik radova u čast Darinki Gortan Premk, Beograd: Filološki fakultet, 275-296.

Prćić, T. (2017b). Englesko-srpski kontrastivni rečnik sinonima: teorijske i praktične osnove. U: S. Gudurić i B. Radić Bojanić (ur.), Jezici i kulture u vremenu i prostoru VI. Tematski zbornik, Novi Sad: Filozofski fakultet, 269287. <http://digitalna.ff.uns.ac.rs/sadrzaj/2017/978-86-6065-432-0>.

Roberts, R. (1992). Organization of Information in a Bilingual Dictionary Entry. In: M. Alvar-Ezquerra (ed.), Euralex '90 Proceedings, Barcelona: Biblograf, VOX, 219-231. < http://euralex.org/category/publications/ euralex-1990/>. 
Sterkenburg, P. van (ed.). (2003). A Practical Guide to Lexicography. Amsterdam/Philadelphia: John Benjamins Publishing Company.

Svensén, B. (2009). A Handbook of Lexicography. The Theory and Practice of Dictionary-Making. Cambridge: Cambridge University Press.

Yong, H. and J. Peng (2007). Bilingual Lexicography from a Communicative Perspective. Amsterdam/Philadelphia: John Benjamins Publishing Company.

Zgusta, L. (1971). Manual of Lexicography. Prague: Academia; The Hague, Paris: Mouton.

Received: 15 November 2017

Accepted for publication: 31 January 2018

Твртко Прћић

\section{СУШТИНСКА СВОЈСТВА ИДЕАЛНОГ ОПШТЕГ РЕЧНИКА: ТЕОРИЈСКЕ ОСНОВЕ}

\section{Сажетак}

У овом раду представљене су и размотрене теоријске претпоставке које би чиниле темељ неког будућег идеалног општег речника. Након Одељка 1 и неколико уводних напомена, које укључују и радну дефиницију идеалног речника, у Одељку 2 укратко су објашњени принципи савремене лексикографије. У Одељку 3 разрађен је теоријски оквир идеалног речника, у три дела која се баве његовом општом карактеризацијом, типолошком идентификацијом и прототипском спецификацијом. У виду закључака, у Одељку 4 рекапитулацију теоријских основа идеалног речника следи сажет преглед перспектива његове практичне реализације.

Кључне речи: идеални општи речник, савремена лексикографија, општа карактеризација, типолошка идентификација, прототипска спецификација 